\title{
A Multi-Criteria Approach for Assessing the Economic Resilience of Agriculture: The Case of Lithuania
}

\author{
Artiom Volkov $\mathbb{D}$, Agnė Žičkienè, Mangirdas Morkunas, Tomas Baležentis * $\mathbb{D}$, Erika Ribašauskienė \\ and Dalia Streimikiene (D)
}

check for

updates

Citation: Volkov, A.; Žičkienè, A.;

Morkunas, M.; Baležentis, T.;

Ribašauskienė, E.; Streimikiene, D. A

Multi-Criteria Approach for

Assessing the Economic Resilience of

Agriculture: The Case of Lithuania.

Sustainability 2021, 13, 2370. https://

doi.org/10.3390/su13042370

Academic Editor: Fabian Capitanio

Received: 21 January 2021

Accepted: 18 February 2021

Published: 22 February 2021

Publisher's Note: MDPI stays neutral with regard to jurisdictional claims in published maps and institutional affiliations.

Copyright: (c) 2021 by the authors. Licensee MDPI, Basel, Switzerland. This article is an open access article distributed under the terms and conditions of the Creative Commons Attribution (CC BY) license (https:/ / creativecommons.org/licenses/by/ $4.0 /)$.
Institute of Economics and Rural Development, Lithuanian Centre for Social Sciences, A. Vivulskio Str. 4A-13, 03220 Vilnius, Lithuania; artiom.volkov@laei.lt (A.V.); agne.zickiene@laei.lt (A.Ž.); morkunas.mangirdas@gmail.com (M.M.); erika.ribasauskiene@laei.lt (E.R.); dalia@mail.lei.lt (D.S.)

* Correspondence: tomas@laei.lt

\begin{abstract}
This study presents an innovative approach to measuring economic resilience at a sectoral level. The notion of economic resilience is explored through the lens of levels of resilience of the main functions of a researched economic sector. The overall level of sectoral economic resilience is seen as a weighted sum of resilience indexes related to its main economic functions. Such a comprehensive approach is universal, as it allows to measure economic resilience of various economic sectors. For the empirical application, the agricultural sector of Lithuania was selected for analysis of resilience. The results revealed that the overall level of resilience declined in Lithuanian agricultural sector during 2012-2019. Such a persistent trend may pose an increasing risk for food security in Lithuania in the future. The most evident negative changes in the economic resilience levels are observed in terms of economic viability of farms. The most robust levels of economic resilience are indicated in the sense of ability to provide local food at affordable prices.
\end{abstract}

Keywords: economic resilience; agriculture; Lithuania; farm viability

\section{Introduction}

The agricultural sector is of the utmost importance to the stable development of a country [1,2]. It ensures employment in rural regions [3], preserves biodiversity [4] balances sociodemographic shifts [5], facilitates economic growth [6] and economic viability during economic downturns [7], assures food security within the country. The assurance of safe, affordable and uninterrupted provision of food within the country always was among the most important goals of the state [8]. It is closely associated with socio-economic development [9], political stability [10], crime rates [11] and even with the satisfaction with democracy [12]. It is assumed that developed countries have solved the food security issues [13]. The recent economic turbulences have evoked concerns about food security even in well-developed countries [14].

The outbreak of pandemic in 2020 disrupted supply chains and various countries started to search for the ways of strengthening the food security and self-sufficiency trying to avoid a risk of food shortages [15]. One of the best ways to increase food security and to foster the supply of local food within the country is to increase the resilience of its agricultural sector [16].

The importance of agricultural sector during crisis is even bigger, as it provides fooda necessary commodity, that could not be avoided even in hardest times [17] assuring a constant financial flow, supporting national economy during economic shocks, when its budget is typically in a depleted state [18]. The decision makers are faced with the ambiguity of the definition of economic resilience notion [19]. It is seen both as a proxy to achieving sustainable agriculture [20] and as independent construct including a sustainability facets as its components [21,22]. The puzzle is becoming even more complex, when economic resilience of agriculture is being researched in the face of climate change, where it is being 
one of the three pillars of climate-smart agriculture. With the help of this paper, we aim to stress the practical side of agricultural economic resilience defining its core functions within a broader state's economic development framework. Such an applied approach provides clear directions to decision makers where to direct Governmental measures aimed at increasing countries economic resilience of agriculture. This paper contributes Morkūnas, Volkov and Pazienza (2018), Michel-Villarreal et al. (2019), Quendler and Morkūnas (2020), Hassani and Fantke (2020) [23-26] insights enriching it with more applied perspective on a meso-economic level. The scientific novelty of the proposed methodology relies on the aggregate-level approach towards resilience of agriculture. Typically, research on agricultural resilience considered micro level data, i.e., farms' economic resilience [27,28], resilience of agricultural holdings [29], resilience of the communities [30]. Moreover, we combine expert assessment and multi-criteria decision-making methods to derive the composite score of the resilience.

The paper is structured as follows: Section 2 introduces different perspectives on the economic resilience notion, defines its core components and functions. In addition, indicators for evaluation of economic resilience in agriculture are discussed. Section 3 describes data gathering process and the evaluation method involved. Section 4 analyzes the dynamics in economic resilience of Lithuanian agriculture. Conclusions and future research are discussed in Section 5.

\section{Theoretical Background}

\subsection{Resilience Concept}

In the last decade the popularity of resilience concept has surged both within the various disciplines as well as among them-it's being used in economy, psychology, agriculture, environmental, physical, political sciences, etc. Politicians and various public bodies are actively adopting this concept too. Resilience is now included in most policy discussions on global sustainability, disaster management and international development [14,31,32]. Resilience takes its share in the European Union political debates about future financial programing period for agriculture as well: it is included as one of the main goals of the upcoming support agenda. However, despite the increasing popularity the resilience concept is still a highly abstract and multifarious concept, which has a great variety of interpretations.

Up to date, two main approaches on resilience are used within the economic literature: the "equilibrium" approaches and the "non-equilibrium" (also called as "complex systems" or "adaptive") approaches [33]. The former ones treat economic systems as relatively simple and homogenous structures, developing in a linear predictable way [34] and refer to resilience as either the ability of the system to return to its pre-shock equilibrium state or growth path it would have been in if the shock was absent $[35,36]$ or as its ability to absorb the shocks that "... have the potential to throw it off its growth path but do not actually do so" [37]. The "bouncing-back" or absorption of the shock should not change the structure of the system nor its social or institutional arrangements. The "non-equilibrium" approaches, on the contrary, treat economic systems as complex and heterogeneous, constantly changing and developing in a hardly predictable way. Since these systems are never in equilibrium, the return to a previous state after a disturbance may not be possible and even desirable (if the system was developing in the non-preferable way). Consequently, the resilience of the system is referred to as a capacity to absorb the perturbation, adapt to it or transform into a better development path not necessarily keeping its structure or social and institutional arrangement unchanged, however maintaining its key functions and performances [38]. "Complex system" approaches, although more complicated, better reflect the real-world economic systems and therefore recently have been gaining more appreciation than the "equilibrium" ones.

In this paper we adopt the complex system approach to resilience and, based on Martin and Sunley (2015) and Meuwissen et al. (2017) [38,39], define the economic resilience of the agricultural sector as the capacity of this sector to withstand or recover from 
various (market, competitive, environmental, etc.) shocks, if necessary by undergoing adaptive changes to its economic structures and social and institutional arrangements, so as to maintain its core performances and functionalities within a given time period. Thus, in order to assess resilience of the agricultural sector, the core functions of this sector have to be identified. Agricultural sector performs various roles, however usually its functions are distinguished into two broad groups according to the type of goods and services provided-either private (representing mainly economic benefits) or public (representing mainly social and environmental benefits) [39].

Private goods provision comprises:

- production of affordable food,

- $\quad$ assurance of farm viability,

- $\quad$ assurance of employment opportunities and appropriate level of income for farm workers.

Public good provision encompasses:

- maintaining natural resources in good condition,

- production of recreational, aesthetic, and cultural services,

- protecting biodiversity of habitats, genes, and species,

- contributing to balanced territorial development,

- climate, flood regulation, disease control.

In some cases, providing some of these goods and services simultaneously can produce significant synergies, however in most cases important trade-offs exist between providing them at a particular scale, as well as between different scales [40]. Accordingly increasing resilience defined in maintaining one function may mean decreasing resilience in providing another function. In this paper the resilience of private good provision (production of food, assurance of farm viability and provision of income) is selected as the core functions of an agricultural sector to be analyzed under the resilience approach. This selection is based on several arguments. First, it best represents the economic dimension of the agriculture and is therefore directly related to economic resilience. Second, it is the primary function of a farming system. Of course, it should be performed taking into consideration public good provisioning, however it is not the other way around (meaning that the primary function is not to maintain biodiversity and in order to do that also produce some food).

Following Martin et al. (2016) [41] who state that maintaining (or restoring) profitability, employment, investment, and growth can be viewed as "core performances and functionalities" in an economic context, provision of income for farm workers, assurance of farm viability and production of affordable food can be legitimately considered as agricultural sector's core functionalities. Therefore, indicators, assessing these performances can be used to assess system's resilience as well. There are various indicator frameworks designed to assess a system's performance regarding its essential functions. A framework suggested by EC (2001) [42] (Table 1) is used as a basis to select the indicators for agricultural sector's performances in this paper.

Production of food is important for several main purposes. First, it has to secure the demand for food in a certain country and the surplus in the form of export produces income for that country and adds to the satisfaction of the global food demand. The indicator "The balance of foreign trade of agricultural and food products" accounts best for both, the local food demand, and the export amounts. Other indicators (such as value of gross production, exports, or imports) are important in special cases; however, in accounting to general resilience they may be abundant. The quantity of aggregated agricultural production (either in amounts or energy terms) is hard and laborious to evaluate, it also does not provide much additional information on the resilience of the function, therefore its usage for assessing resilience is of relatively little value. The level prices of agricultural products are very important, since it determines the type, quantity, and quality of the produce that people of a certain country can afford to consume. However, its level also depends on the general inflation, therefore the best indicator for affordable prices could be the ratio of the retail prices of agricultural and food products to the retail prices of all consumption goods. 
Table 1. Indicator framework for assessing performances of the agricultural sector.

\begin{tabular}{|c|c|c|c|}
\hline Functior & & State Indicators & Flow Indicators \\
\hline \multirow{8}{*}{$\begin{array}{l}\text { Production of } \\
\text { food at } \\
\text { affordable prices }\end{array}$} & \multirow{5}{*}{ Value } & Value of gross production in agriculture & $\begin{array}{l}\text { Change of value of gross production in } \\
\text { agriculture }\end{array}$ \\
\hline & & Gross value added at nominal prices & Change in gross value added \\
\hline & & Value of exported agricultural products & $\begin{array}{l}\text { Change in value of exported agricultural } \\
\text { products }\end{array}$ \\
\hline & & Value of imported products & $\begin{array}{l}\text { Change in value of imported agricultural } \\
\text { products }\end{array}$ \\
\hline & & $\begin{array}{l}\text { Foreign trade balance of agricultural and } \\
\text { food products }\end{array}$ & $\begin{array}{l}\text { Change in the foreign trade balance of } \\
\text { agricultural and food products }\end{array}$ \\
\hline & Quantity & $\begin{array}{l}\text { Quantity (in energy terms) } \\
\text { Quantity (in amounts) }\end{array}$ & Change in quantity \\
\hline & \multirow[b]{2}{*}{ Prices } & Retail prices of agricultural and food products & $\begin{array}{l}\text { Change in retail prices of agricultural and } \\
\text { food products }\end{array}$ \\
\hline & & $\begin{array}{l}\text { The ratio of the retail prices of agricultural and } \\
\text { food products to the retail prices of all } \\
\text { consumption goods }\end{array}$ & $\begin{array}{l}\text { Change in ratio of retail prices of agricultural } \\
\text { and food products to the retail prices of all } \\
\text { consumption goods }\end{array}$ \\
\hline \multirow{7}{*}{\multicolumn{2}{|c|}{ Farm viability }} & Net farm income & Change in net farm income \\
\hline & & Distribution of profit & Change in distribution of profit \\
\hline & & Debt/asset ratio & Change in debt/asset ratio \\
\hline & & Number of forced farm exits & Change in number of forced farm exits \\
\hline & & Value added (Farm net value added/AWU) & Change in value added \\
\hline & & Farm profitability & Change in farm profitability \\
\hline & & Access to credit & Change in access to credit \\
\hline \multirow{5}{*}{\multicolumn{2}{|c|}{ Employment and Income }} & Income of agricultural workers & Change in income of agricultural workers \\
\hline & & Ratio of income of agricultural workers to the & Change in ratio of income of agricultural \\
\hline & & average salary in the country & workers to the average salary in the country \\
\hline & & Employment in agriculture & Change in employment in agriculture \\
\hline & & $\begin{array}{l}\text { Share of agricultural employment in the general } \\
\text { employment level in the country }\end{array}$ & $\begin{array}{l}\text { Change in share of agricultural employment in } \\
\text { the general employment in the country }\end{array}$ \\
\hline
\end{tabular}

Source: adapted from [42] with authors' own elaborations.

Farm viability has been estimated in several ways [43]. The most often used indicators include farm net income, profitability, distribution of profit, debt/asset ratio, etc. To create an easily replicable measurement of agricultural resilience, the indicators used must reflect main and different aspects of farm viability; they must also be easily accessible and comparable among different countries. Farm profitability, debt to asset ratio and access to credit best correspond to these requirements.

The function "assurance of employment opportunities and appropriate level of income for farm workers" is an important function, however it raises several questions. First, employment in agricultural sector is declining in many countries due to the use of advanced technologies and better technical equipment, diminishing labor demand. Relatively low productivity in this sector as compared to the other economic activities makes it economically reasonable to transfer labor supply from agricultural sector to the others. However, since a large share of these employees has relatively low qualifications and is near or above the retirement age, their flexibility in the labor market is questionable. Therefore, the fast decrease in employment in agriculture may not be preferable. Considering the demographic changes and changes in the structure of the whole economy, the best indicator to reflect the employment in agriculture is applying the indicator "Ratio of employment in agriculture to the general employment level in the country". Ratio of income of agricultural workers to the average salary in the country also better reflects the level of wages than the income of agricultural workers alone since it allows accounting for general inflation.

Since resilience is relevant mainly in the cases of perturbations, it makes sense to refer to resilience as a change of relevant indicators (i.e., use flow indicators) instead of their absolute or relative levels (i.e., instead of state indicators) at the time of crisis. 
On the other hand, resilience is mostly "grown" before perturbation happens [44] and the reaction to the shock to a large extent is determined by the before-grown capacities and decisions (e.g., skills and knowledge of managers and employees, adequate infrastructure, social capital, connectivity, etc.). Thus, in order to compare the development of the general resilience capacity in the periods of stability as well as its decline in the case of crisis, the absolute or relative levels of relevant indicators could be used $[45,46]$. Therefore, in this paper resilience is related to absolute/relative levels of relevant indicators.

It must also be noted that in this paper general resilience as opposed to 'specified' resilience is being explored, focusing on the capacity of a system to react to various kinds of shocks and perturbations, instead of dealing with a particular kind shock or particular aspect of the system that might be affected by that shock [40].

\subsection{Resilience Measurement}

Since resilience is a latent construct, the variety of approaches has stimulated the creation of a great diversity of resilience measurement ways and methods. Several of them are provided in Table 2. Some researchers $[40,47,48]$ argue, that resilience is a too complex and constantly changing construct and therefore cannot be measured directly (or it is too difficult and costly to be measured), thus they propose using surrogate indicators (e.g., socially self-organized, appropriately connected, exhibiting functional and response diversity, building on human capital, reasonably profitable, globally autonomous and locally interdependent, constantly learning, etc. [47] to measure resilience. Systems in which these surrogate indicators exhibit relatively high-performance levels are supposed to better resist and adapt to perturbations, while poor levels of their performances indicate low resilience. Although these surrogate indicators enable better understanding of the situation in a respective area and empower better interventions, they have their own drawbacks. If these indicators are performing differently and tend to evolve in different directions (some increase, other decrease), it is hard to form a view of how an economic system is resilient in general. It is also hard to compare its evolution in time as well as with other economic systems.

Table 2. Some of the methods, used for economic resilience measurement.

\begin{tabular}{|c|c|c|c|}
\hline & Measurement of Resilience & Method & Examples \\
\hline \multirow{6}{*}{ Indices } & $\begin{array}{l}\text { General resilience index based on factors, } \\
\text { influencing resilience }\end{array}$ & Multicriteria evaluation methods & {$[23,49-51]$} \\
\hline & \multirow{5}{*}{$\begin{array}{l}\text { Resilience index, based on the measurements of } \\
\text { core function/-s of a particular system (e.g., GDP } \\
\text { or employment for a country) }\end{array}$} & $\begin{array}{l}\text { Simple statistics of the main functions (e.g., } \\
\text { deviation from the average, growth trajectory, etc.). }\end{array}$ & {$[29,52]$} \\
\hline & & Simulations (counterfactual analysis). & [53] \\
\hline & & $\begin{array}{l}\text { Statistical time series models (estimating time length } \\
\text { necessary to eliminate the impact of a shock). }\end{array}$ & {$[35]$} \\
\hline & & $\begin{array}{l}\text { Optimization models (minimizing consumption } \\
\text { losses for a given amount of capital losses). }\end{array}$ & {$[54,55]$} \\
\hline & & $\begin{array}{l}\text { Case studies (mainly narrative-based, some simple } \\
\text { statistics included) }\end{array}$ & [56-58] \\
\hline & Surrogate indicators & $\begin{array}{l}\text { Increasing/decreasing values of surrogate indicators } \\
\text { reflect increase/decrease of resilience }\end{array}$ & {$[40,47,48,59]$} \\
\hline
\end{tabular}

Source: compiled by authors.

The majority of researchers prefer creating resilience indices, either single or composite. These indices and their calculation methods however do significantly differ among each other. First, there can be two main types of indices distinguished: general resilience index computed from a variety of economic, social, human, environmental and political factors of resilience [50]. The weights of factors are determined in several ways and are either equal among each other or differ according to the method applied. This way 
of resilience assessment has several advantages. First, it allows its users to see what factors influence resilience and how strong that influence is. It also enables following the development trends of these factors and detect the ones, most in need for intervention. However, a serious disadvantage of a general index is that it is very subjective of how many and which indicators should be included in the computation of the index as well as of what weights should be assigned for each of the selected variables. Since every economic system is a complex system, the indicators determining resilience of that system or their importance (or weight) may vary. Thus, the replicability of the resilience index among relevant economic systems may be both difficult and laborious or of little value. Besides that, since complex systems are constantly changing, some indicators may lose their importance or new indicators may obtain more significance, therefore such indices have to be updated from time to time.

The other way of measuring resilience via an index is by composing it from the indicators, reflecting the key functions of the particular system, e.g., employment and GDP are usually considered to be the main functions of a regional or national economy, therefore the level of these indicators or the change in their level reflects the resilience of the regional (state) economy at a particular time point [60]. The latter method of resilience index calculation is preferred by many researchers $[21,22,61,62]$ for it allows focusing on the change of the key functions instead of variables influencing those functions. Thus, following the definition of resilience adopted in this paper (the capacity to withstand or recover from shocks maintaining the core performances and functionalities), this way allows directly observing resilience and changes in it. It enables avoiding the disadvantages of the above-mentioned general index calculation methods, such as difficulties in selecting the potential factors from a large group of possible ones, determining their weights, and updating these weights in time. The indices based on key functions are much easier (and less time-costly) to calculate, to interpret, to compare and to replicate. Their main disadvantage is the inability to reveal the factors leading to the loss (or increase) of resilience. However, the general indices would not necessarily disclose these factors either since they may be omitted in the calculations.

\section{Methods}

Based on the above review of resilience evaluation methods, their advantages and disadvantages, we choose to assess resilience of the agricultural sector via an index, composed of the variables reflecting the core functions of the sector. The core functions of the agricultural sector encompass production of affordable food, assurance of farm viability and provision of employment opportunities with decent income for agricultural workers (Table 3).

Table 3. Core functions of the agricultural sector and their indicators for measuring agricultural resilience.

\begin{tabular}{|c|c|c|}
\hline Function & Indicators of the Function & Unit \\
\hline \multirow{2}{*}{$\begin{array}{l}\text { Production of food at } \\
\text { affordable prices }(\mathrm{F})\end{array}$} & Foreign trade balance of agricultural and food products & mil. EUR \\
\hline & $\begin{array}{l}\text { Ratio of the retail prices of agricultural and food } \\
\text { products to the retail prices of all consumption goods }\end{array}$ & $\%$ \\
\hline \multirow{3}{*}{$\begin{array}{l}\text { Assurance of farm } \\
\text { viability }(\mathrm{V})\end{array}$} & Farm profitability & $\%$ \\
\hline & Farm solvency & $\%$ \\
\hline & Access to credit & $\%$ \\
\hline \multirow{2}{*}{$\begin{array}{c}\text { Provision of employment } \\
\text { opportunities with decent } \\
\text { income for agricultural } \\
\text { workers (E) }\end{array}$} & $\begin{array}{l}\text { Ratio of income of agricultural workers to the average } \\
\text { salary in the country }\end{array}$ & $\%$ \\
\hline & $\begin{array}{l}\text { Share of agricultural employment in general } \\
\text { employment in the country }\end{array}$ & $\%$ \\
\hline
\end{tabular}

Source: compiled by authors.

Lithuania is chosen as a case for empirical analysis as this country has seen serious agricultural restructuring and growth following its accession to the European Union in 2004. 
This pattern is also pertinent to a number of Eastern European countries where accession to the EU marked a series of structural changes. The introduction of the EU Common Agricultural Policy in Lithuania fueled structural changes that affected resilience indicators, among other effects. In order to avoid drawing conclusions from the transitory periods, we ignore the accession year and five years thereafter. Therefore, the research focuses on the period of 2010-2019. The data come from Statistics Lithuania and Farm Accountancy Data Network (FADN).

In order to calculate the resistance index according to the functions defined in Table 3 and the selected indicators assigned to the functions, the multi-criteria decision-making method Simple Additive Weighting (SAW) was applied. This approach is highly operational and relies on the additive function.

Let there be an index of the resilience functions, $k=\{F, V, E\}$. In addition, let $i$ and $j$ index the indicators and time periods respectively. Then, $r_{k i j}$ is the value of the $i$-th resilience indicator in the $k$-th function for the $j$-th year.

The ratios are calculated to perform the normalization. The benefit indicators were normalized by [63]:

$$
\widetilde{r}_{k i j}=\frac{r_{k i j}}{\max _{j} r_{k i j}}
$$

Similarly, the following ratios were calculated to normalize the cost criteria [63]:

$$
\widetilde{r}_{k i j}=\frac{\min _{j} r_{k i j}}{r_{k i j}}
$$

The weighted sums of the normalized values are calculated for each year and function:

$$
S_{k j}=\sum_{i=1}^{m_{k}} w_{k i} \widetilde{r}_{k i j}
$$

where $w_{k i}$ is the weight of the $i$-th indicator for function $k$ such that $\sum_{i=1}^{m_{k}} w_{k i}=1, k=\{F, V, E\}$.

In this way, the sub-indicators representing resilience functions were calculated. The comprehensive indicator comprising all functions $k=\{F, V, E\}$ functions, the formula applied:

$$
S_{j}=\sum_{k=\{F, V, E\}} q_{k} S_{k j}
$$

where $q_{k}$ are the weights of resilience functions and $\sum_{k=\{F, V, E\}} q_{k}=1$.

The composite indicator $S_{j}$ takes values in between 0 and 1 where the value of unity indicates maximum performance.

To calculate the weights of functions and indicators, an expert survey was carried out. Fifteen experts equally representing academia, government and farm associations were invited to rate the functions and indicators. The criterion for eligibility of experts was experience in the field of agriculture (science, policy or implementation) for at least 5 years.

\section{Results and Discussion}

The assessment of Lithuanian agricultural resilience was divided into analyses of three functions. The analysis of indicators for Function F (foreign trade balance of agricultural and food products, and ratio of retail prices indices of food products to retail price indices of all consumption goods) showed that the situation in this area is quite positive. The foreign trade balance is positive and growing (Figure 1). The sudden rise of the balance in 2019 is mainly due to the increase in exports of milk and crop products, generating the largest share of all Lithuania's agricultural and food exports. 


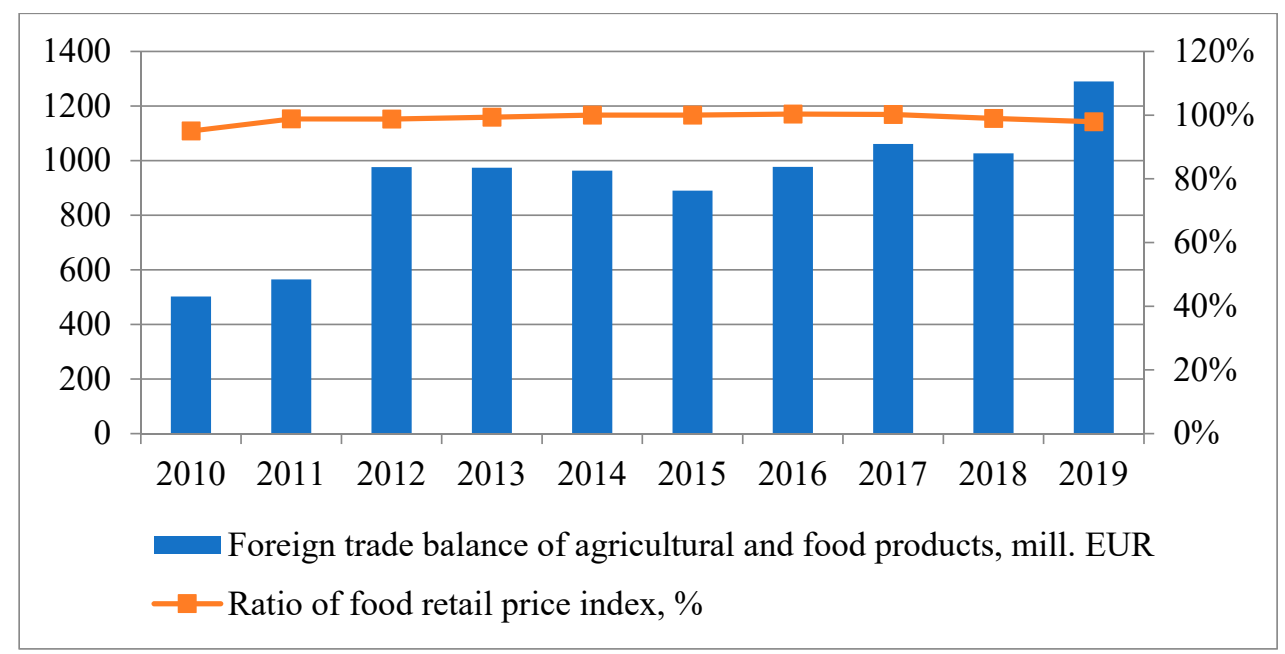

Figure 1. Foreign trade balance of agricultural and food products and Ratio of retail price indices of food products to retail price indices of all consumption goods, EUR, \% (year $2015=100$ proc.). Source: compiled by authors based on the data provided by Statistics Lithuania.

The growth of retail prices of food products and non-alcoholic drinks has been faster in 2017-2018 year-period than a period before, however this growth was not exceptional, actually even smaller than the growth of the prices of the other consumption goods.

Assessing indicators of $V$ function (farm profitability, solvency and access to credit), it was found, that profitability (farm profitability $=$ (total output - total inputs + total subsidies excluding on investments) divided by total output) of farms in Lithuania is very unstable and has a tendency to decline. Although every two years it partly recovers, however it does not reach previous levels (Figure 2). This negative trend is observed despite the significant incoming cash flows arising EU and state support schemes (direct payments, payments for ecological farming, payments for farming in less favored areas and other production subsidies, not including subsidies on investments). The average amount of subsidies received in 2010-2019 accounted to more than one third of the total output. The performance of farms without support would be unprofitable even in the long run, i.e., most farms (except for the largest ones) would be unviable and would be forced to exit the business.

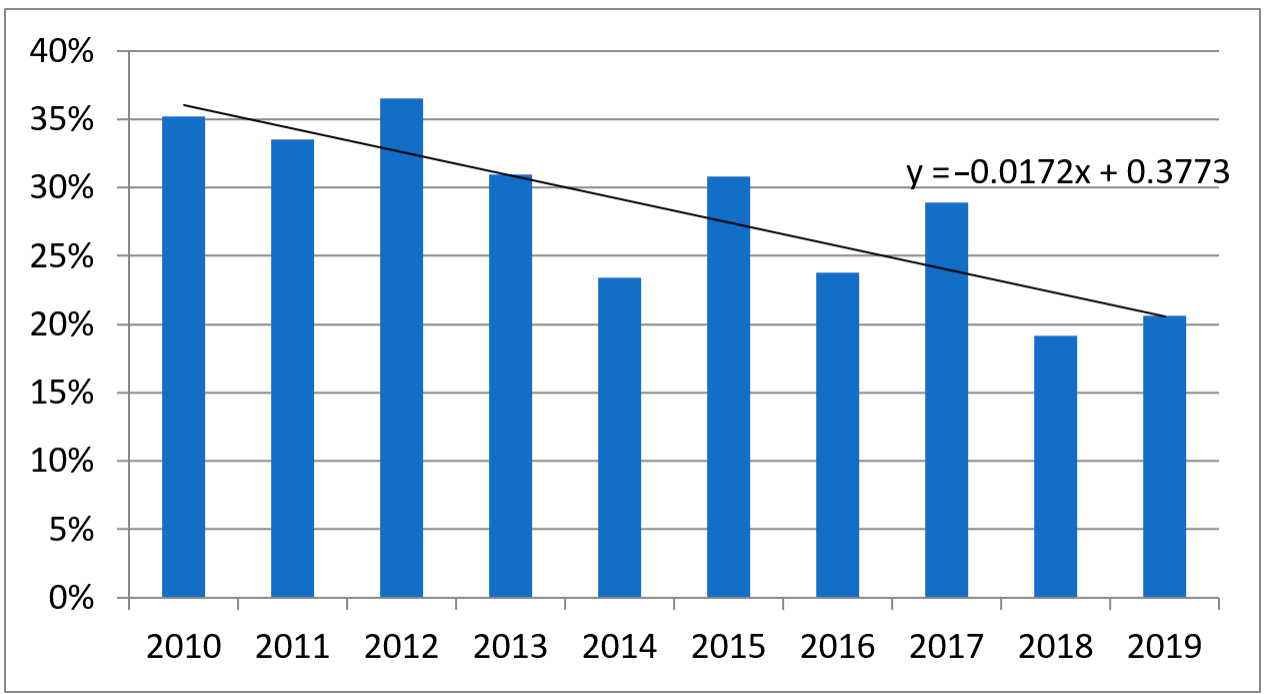

Figure 2. Average farm profitability in Lithuania in 2010-2019, \%. Source: compiled by authors using FADN data. 
The changes of solvency (Farm solvency = profit with subsidies before external factors (interest, taxes and depreciation) divided by total liabilities.) (the other farm viability indicator) in the last decade also reflects negative tendencies. Unstable farm profits and increasing amounts of debt lessen farms' abilities to repay their credits. Farm solvency in Lithuania in 2010-2019 year-period has decreased around 65\% on average (Figure 3).

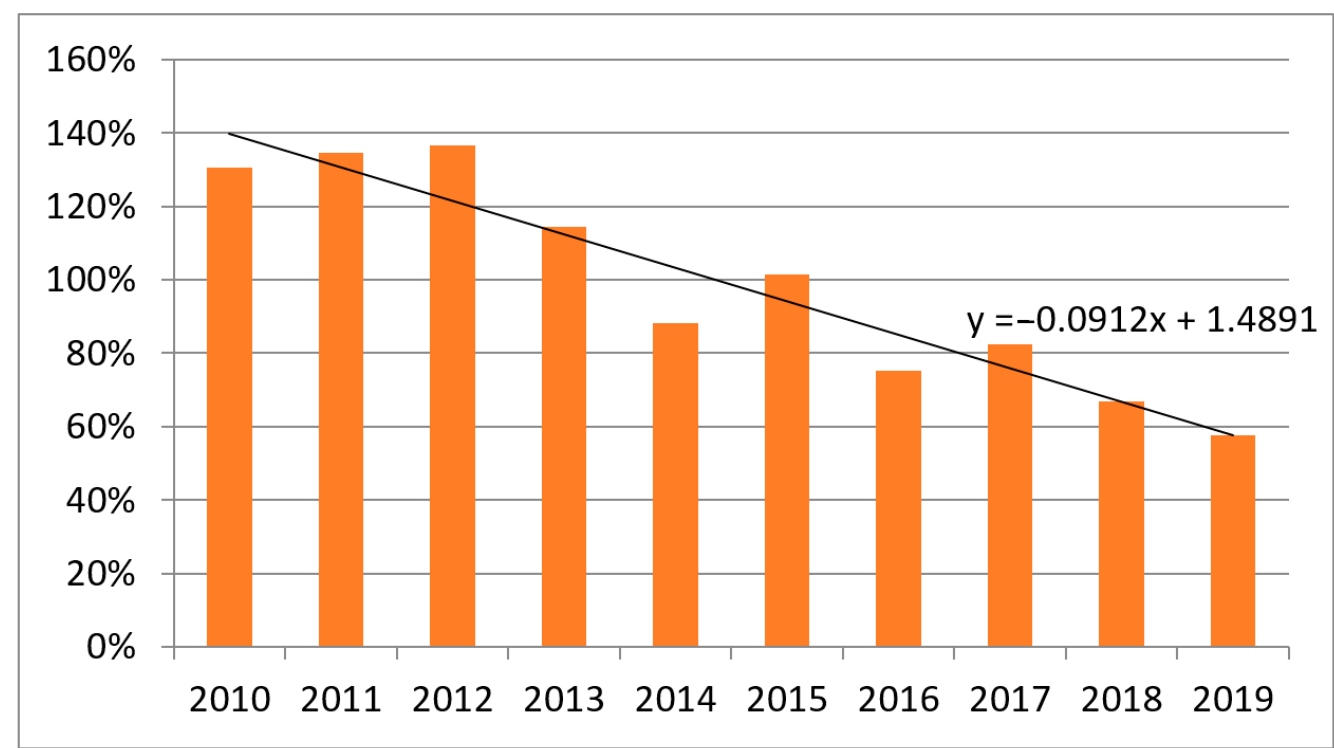

Figure 3. Average farm solvency in Lithuania in 2010-2019, EUR, \%. Source: compiled by authors using FADN data.

Access to credit is measured as a share of provided credits out of all applications for credit (both satisfied and unsatisfied). Although the amounts of loans provided for agricultural subjects have been increasing every year in the last decade, the biggest share of total credits is issued for large farmers' farms or agricultural holdings, while access to financial resources for other farms is very limited. Based on Fi-compass [64] study and expert evaluations, only about $20 \%$ to $30 \%$ of all credit applications are being satisfied. The majority of loan request are rejected for small-farm and young managers due to the higher risk and absence of credit history.

Analyzing the indicators of Function E (the share of occupied labor posts in agriculture in all occupied labor posts in the country and by the ratio of wages in agriculture to average wages in all economic activities), it was established that in the last five years the employment in agriculture has been decreasing, however the speed of diminution has increased in the last two years, whereas the employment in other economic sectors has been slowly but steadily growing. Therefore, the share of occupied posts in agriculture out of all occupied labor posts in Lithuania has been gradually decreasing (Figure 4). Although the decline in employment in agriculture corresponds to the trends in most EU states, however the speedy decrease elicits many serious economic and social problems in rural areas. This decrease in occupied labor posts is determined not only by technological improvements, but also by large numbers of farm exists out of the market. Due to the above mentioned low and declining farm profitability as well as retirement of farmers (senior farmers compose a large share of all farmers) the previous levels of demand for labor in agricultural sector cannot be sustained. 


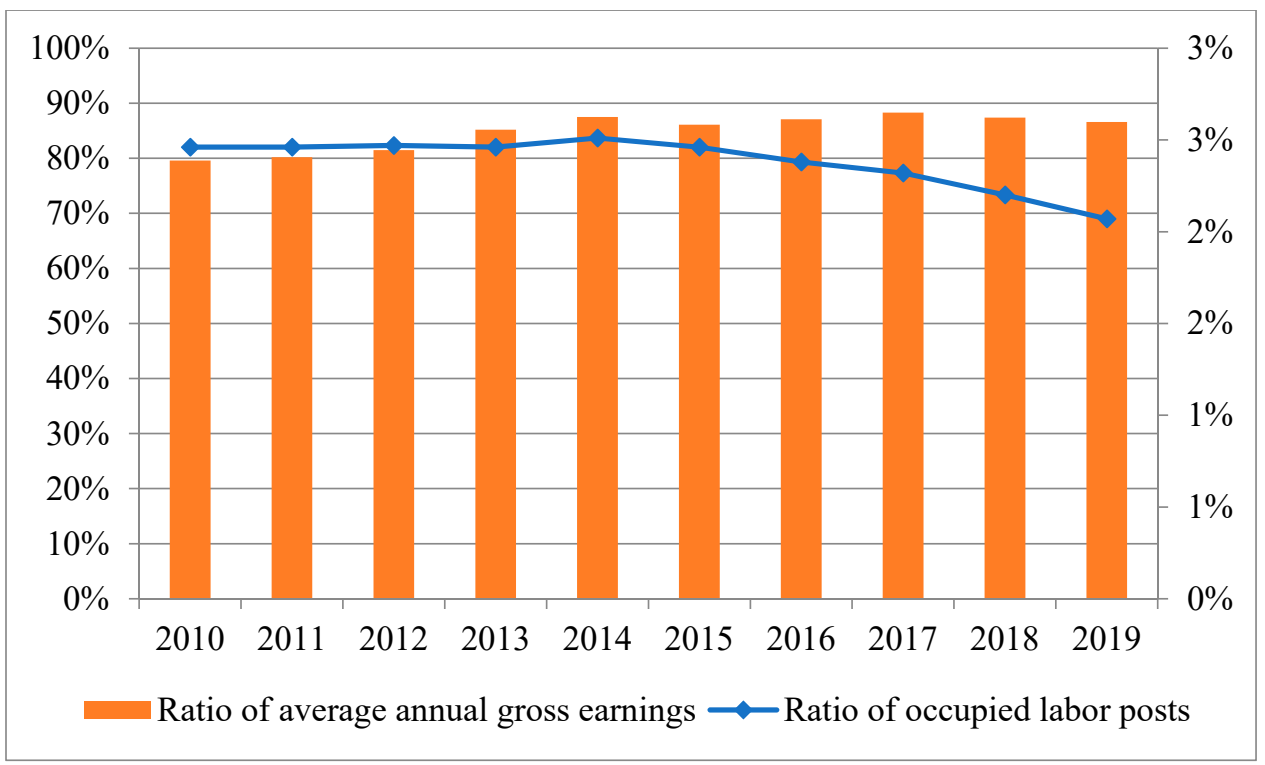

Figure 4. Share of occupied agricultural labor posts in all occupied labor posts and Ratio of average annual gross earnings in Agriculture, forestry and fishing to earnings in all NACE branches in 2010-2019, \%. Source: compiled by authors based on the data provided by Statistics Lithuania.

Average wages in agricultural sector in Lithuania have been growing the whole 20102019 year-period, however the whole period it was lower than the average earnings in the country. In 2010 this difference was larger than $20 \%$, whereas in 2017 it decreased up to $12 \%$. Unfortunately, in the last two years the difference has started to grow again.

The values of all indicators used to evaluate the above functions are presented in the Table 4.

Table 4. Values of indicators used to create the resilience index of the agricultural sector in Lithuania by functions, $2010-2019$.

\begin{tabular}{|c|c|c|c|c|c|c|c|}
\hline \multirow{2}{*}{$\begin{array}{c}\text { Function } \\
\text { Source }\end{array}$} & \multicolumn{2}{|c|}{$\begin{array}{c}\text { Production of Food at Affordable } \\
\text { Prices (F) }\end{array}$} & \multicolumn{3}{|c|}{ Assurance of Farm Viability (V) } & \multicolumn{2}{|c|}{$\begin{array}{c}\text { Provision of Employment } \\
\text { Opportunities with Decent Income for } \\
\text { Agricultural Workers (E) }\end{array}$} \\
\hline & $\begin{array}{l}\text { Statistics } \\
\text { Lithuania }\end{array}$ & $\begin{array}{l}\text { Statistics } \\
\text { Lithuania }\end{array}$ & FADN & FADN & $\begin{array}{l}\text { FADN (own } \\
\text { estimation) }\end{array}$ & $\begin{array}{l}\text { Statistics } \\
\text { Lithuania }\end{array}$ & $\begin{array}{l}\text { Statistics } \\
\text { Lithuania }\end{array}$ \\
\hline Type & Benefit (+) & Cost $(-)$ & Benefit (+) & Benefit $(+)$ & Benefit (+) & Benefit $(+)$ & Benefit $(+)$ \\
\hline Indicator & $\begin{array}{l}\text { Foreign trade } \\
\text { balance of } \\
\text { agricultural and } \\
\text { food products, } \\
\text { mil. EUR }\end{array}$ & $\begin{array}{l}\text { Ratio of the retail } \\
\text { prices of } \\
\text { agricultural and } \\
\text { food products and } \\
\text { the retail prices of } \\
\text { all consumption } \\
\text { goods } 1, \%\end{array}$ & $\begin{array}{l}\text { Farm } \\
\text { profitability, \% }\end{array}$ & $\begin{array}{l}\text { Farm } \\
\text { solvency, } \\
\quad \%\end{array}$ & $\begin{array}{l}\text { Access to } \\
\text { credit, } \%\end{array}$ & $\begin{array}{l}\text { Ratio of income } \\
\text { for agricultural } \\
\text { workers and } \\
\text { average salary in } \\
\text { the country }{ }^{2}, \%\end{array}$ & $\begin{array}{c}\text { Share of } \\
\text { employment in } \\
\text { agriculture and } \\
\text { general } \\
\text { employment level } \\
\text { in the country }{ }^{3}, \%\end{array}$ \\
\hline 2010 & 502 & $95.0 \%$ & $35.2 \%$ & $130.4 \%$ & $17.9 \%$ & $2.46 \%$ & $79.6 \%$ \\
\hline 2011 & 565 & $98.8 \%$ & $33.5 \%$ & $134.6 \%$ & $18.4 \%$ & $2.46 \%$ & $80.2 \%$ \\
\hline 2012 & 976 & $98.7 \%$ & $36.5 \%$ & $136.6 \%$ & $19.0 \%$ & $2.47 \%$ & $81.5 \%$ \\
\hline 2013 & 974 & $99.3 \%$ & $30.9 \%$ & $114.3 \%$ & $18.9 \%$ & $2.46 \%$ & $85.2 \%$ \\
\hline 2014 & 963 & $100.0 \%$ & $23.4 \%$ & $88.1 \%$ & $19.5 \%$ & $2.51 \%$ & $87.5 \%$ \\
\hline 2015 & 890 & $100.0 \%$ & $30.8 \%$ & $101.5 \%$ & $20.1 \%$ & $2.46 \%$ & $86.1 \%$ \\
\hline 2016 & 977 & $100.3 \%$ & $23.8 \%$ & $75.1 \%$ & $20.8 \%$ & $2.38 \%$ & $87.1 \%$ \\
\hline 2017 & 1061 & $100.2 \%$ & $28.9 \%$ & $82.4 \%$ & $21.4 \%$ & $2.32 \%$ & $88.3 \%$ \\
\hline 2018 & 1027 & $98.9 \%$ & $19.2 \%$ & $66.8 \%$ & $21.7 \%$ & $2.20 \%$ & $87.4 \%$ \\
\hline 2019 & 1290 & $97.9 \%$ & $20.6 \%$ * & $57.7 \%$ * & $22.16 \%$ & $2.07 \%$ & $86.6 \%$ \\
\hline
\end{tabular}

${ }^{1}$ Change in the retail price index of food and non-alcoholic beverages compared to the change in the price index of all consumer goods $(2015=100 \%) .{ }^{2}$ Ratio of employment in agriculture, forestry, and fishing (excluding seasonal and working day effects) to total employment in the country. ${ }^{3}$ Ratio of wages (annual gross) in agriculture, forestry, and fishing to the average annual wage in the country. ${ }^{*}$ Forecast. Source: authors' calculations based on Statistics Lithuania and FADN database. 
Since both the individual functions and the overall resilience are defined by indicators, in order to calculate the sub-indices, the weights of the indicators were calculated on the results of the expert survey basis (Table 5).

Table 5. Weights of indicators by individual functions (results of expert evaluation).

\begin{tabular}{|c|c|c|}
\hline Function & Indicators of the Function & Weights $(w)$ \\
\hline \multirow{2}{*}{$\begin{array}{l}\text { Production of food at affordable } \\
\text { prices }(\mathrm{F})\end{array}$} & Foreign trade balance of agricultural and food products & $52 \%$ \\
\hline & $\begin{array}{c}\text { Ratio of the retail prices of agricultural and food products and the retail } \\
\text { prices of all consumption goods }\end{array}$ & $48 \%$ \\
\hline \multirow{3}{*}{ Assurance of farm viability (V) } & Farm profitability & $30 \%$ \\
\hline & Farm solvency & $37 \%$ \\
\hline & Access to credit & $33 \%$ \\
\hline \multirow{2}{*}{$\begin{array}{l}\text { Provision of employment } \\
\text { opportunities with decent income } \\
\text { for agricultural workers }(E)\end{array}$} & Ratio of income for agricultural workers and average salary in the country & $53 \%$ \\
\hline & $\begin{array}{c}\text { Share of employment in agriculture and general employment level in the } \\
\text { country }\end{array}$ & $47 \%$ \\
\hline
\end{tabular}

Source: compiled by authors.

The answers of the experts in assessing the weights of the indicators were consistent. Concordance coefficient of expert answers in estimating the weights for function F indicators $\left(\mathrm{W}_{\mathrm{F}}\right)$ is equal to 0.57 ; for $\mathrm{V}$ function's indicators: $\mathrm{W}_{\mathrm{V}}=0.70$; $\mathrm{E}$ function's: $\mathrm{W}_{\mathrm{E}}=0.54$.

According to function F (production of food at affordable prices), the foreign trade balance of agricultural and food products (compared to ratio of retail prices) is considered to be a relatively more important indicator (Table 5). In function $V$ (assurance of farm viability), the solvency of farms is considered to be the relatively most important indicator. In function E (provision of employment opportunities with decent income for agricultural workers), the average salary in the sector is the most important indicator.

Examining the importance indicated by the experts of the functions for the overall resilience of the agricultural sector in Lithuania, it can be stated that the experts consider all three identified functions of the agricultural sector to be important-the difference between the importance of individual functions is less than 10\% (Table 6). However, the sector's ability to provide the population with affordable food (function F) is considered to be a relatively important function, accounting for $38 \%$ out of $100 \%$. Relatively least important (function E) is the provision of employment opportunities with decent income for agricultural workers ( $28 \%$ out of $100 \%$, respectively).

Table 6. Weights of individual function (results of expert evaluation).

\begin{tabular}{cc}
\hline Function & Weights $(q)$ \\
\hline Production of food at affordable prices (F) & $38 \%$ \\
\hline Assurance of farm viability (V) & $34 \%$ \\
\hline $\begin{array}{c}\text { Provision of employment opportunities with decent income for agricultural } \\
\text { workers (E) }\end{array}$ & $28 \%$ \\
\hline Source: compiled by authors. &
\end{tabular}

Source: compiled by authors.

After normalization of the data, calculation of the weights of the functions and imputation of the indicators, the total resistance index of the agricultural sector and subindexes of individual functions was calculated. The data for 2010-2019 were applied. The SAW method was used. The results are provided in Figure 5. 


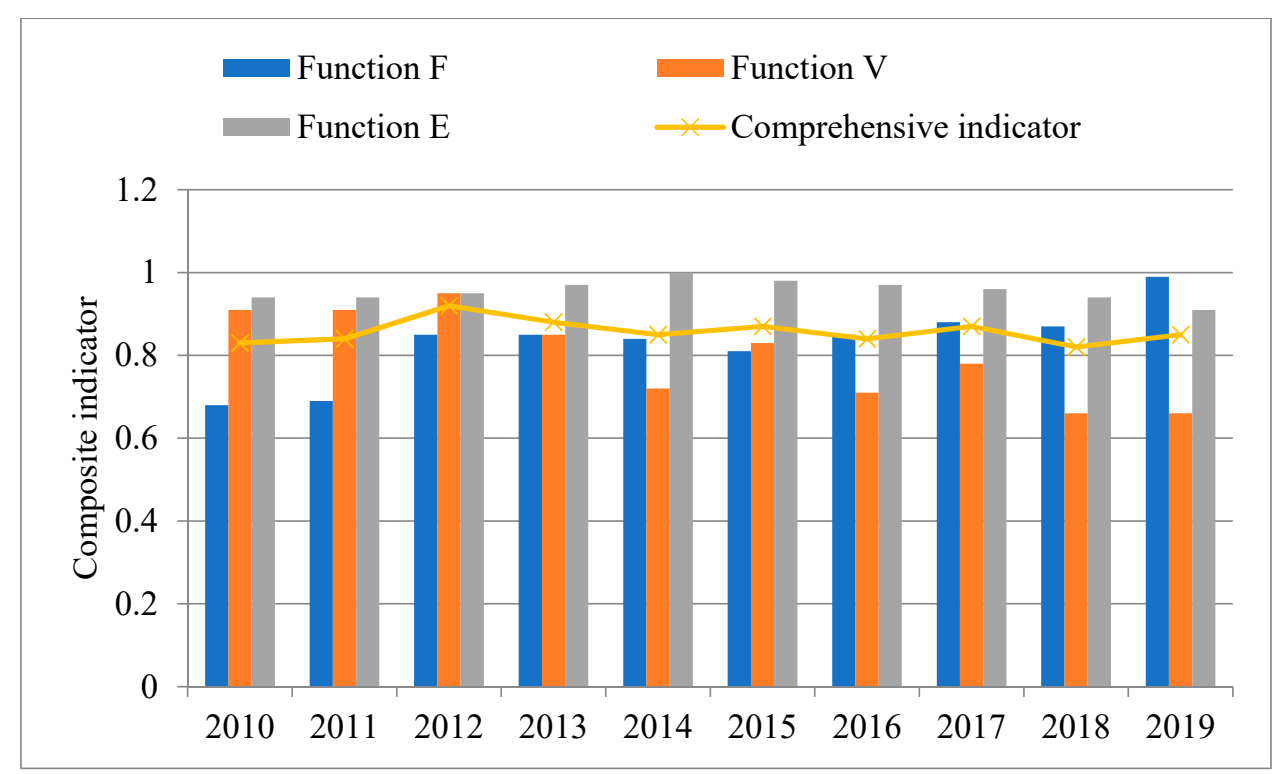

Figure 5. The values of the sub-index of the agricultural sector resilience by individual functions and the values of the general sector resilience index in Lithuania in 2010-2019. Source: compiled by authors

The overall resilience indicator for Lithuania shows a slightly downward trend. The overall resilience of the agricultural sector is most negatively affected by the decline in farm viability. Farm profitability has been declining for almost a decade (table), and farm solvency has been declining, too. This is a dangerous trend, as a sharp drop in farm profitability in the long run could lead to farms withdrawing from the market. Although access to credit tends to grow, this growth is relatively very slow. As a result, the overall farm viability index fell by about $30 \%$ in 2019 compared to 2012. The viability function of farms is particularly important, as the level of implementation of other agricultural functions also depends on it. If the number of commercial farms decreases significantly, the level of supply of agricultural products (at least some) may decrease. Production prices should increase accordingly. Declining farm viability may also have a negative impact on labor demand and, as a result, lead to lower wages in the sector. Therefore, to increase the overall resilience of agriculture, the first focus should be on increasing farm viability. Especially since the resilience of other functions is at a sufficiently high level. During the period under review, the resilience subindex of the production of food at affordable prices function increased significantly, almost reached 0.99 (in comparison to the data of 2010-2019). It is true that the supply of different types of agricultural products changed differently-the supply of cereals increased significantly, while the supply of vegetables, fruit and berries decreased.

However, Function $F$ has gained more importance in the sense of contribution to the overall resilience indicator during the last years. Function $\mathrm{E}$ is related to employment opportunities with decent income for agricultural workers. These have been declining in the sector over the last five years. Thus, the composite indicator for Function E reached its low in 2019 at 0.91 . Note that the levels of the composite resilience indicators are relative ones, i.e., determined in relation to other values from the period under consideration.

The decline in the resilience due to employment opportunities is mainly due to productivity growth and technical bias in the sector. The new technologies that reduce the need for labor fuel such changes. The declining employment in agricultural sector (faster than in other economic activities) is in line with the trends in other EU countries as well. To sum it up, the overall resilience of the agricultural sector in Lithuania is declining. The most unstable and threatening situation is observed in regards to farm viability. Increasing farm viability would also have a positive impact on other key functions of the sector and the overall level of resilience. 


\section{Conclusions}

The economic resilience still can be considered to be an ambiguous notion displaying varying interpretations. The present study contributes to lowering the level of flux in an economic resilience notion by substantiating its research possibility through the lens of its facets in an applied research framework.

From the methodological perspective this study suggests a new innovative universal framework for measuring a sectoral economic resilience through the lens of economic resilience of its main functions. This approach allows measuring economic resilience of various economic sectors, where previous research methods were unsuitable due to sectors complexity or specifics, not allowing to apply the methodologies used in measuring economic resilience in other areas [65]. The introduction of such a universal research approach may contribute to the intensification of economic resilience research and expansion of it to various related areas and sectors.

This study also suggests some practical implications. Sub-indicators and their trends reflect changes in resilience (with regards to each function). Such information can be used by public agencies as a warning information system indicating a necessity of intervention in a certain problematic area. The composite indicators can also be used to prioritize intervention directions. Since resilience indicator and its sub-indicators are based on a set of function, policy makers can develop intervention measures targeted to a particular area in need. Thus, the comprehensive indicator allows tracking the development of resilience of a particular sector, modelling the effects of potential intervention measures and evaluating the effects of factual interventions on resilience of the whole sector.

The research revealed that crucial factor in maintaining the economic resilience of agriculture is the economic viability of farms. The observed decreasing trend not only calls for some interventions from the government side, but is also consistent with Coppola et al. (2020) [66] insights about decreasing farm viability within EU and their dependency on EU support [67]. The value of the farm viability composite indicator decreased by $30 \%$ in Lithuania posing a risk to the robustness of economic resilience of agriculture in the future. In Lithuania, the affordable food component of economic resilience showed a steadily high level during 2010-2019. The direct payments can be considered as a major cause for maintaining low food prices [68]. The decreasing values of the employment component implies that, on the long run, agriculture will cease being a major job provider in Lithuanian rural areas which will induce issues related to transition towards other sources of employment [69].

The limitations of this study (empirical evidence based only on one country) suggest expanding this research to a broader range of countries. This would allow revealing if the trend of declining economic resilience (especially, in terms of farm viability) prevails across the EU, or it is characteristic to Lithuania only. A natural direction for such research would be exploring agricultural resilience in the Central and Eastern European countries. Another research avenue is covering a longer time period in order to investigate the influence of various exogenous factors (recession of 2008, accession to EU etc.) on the dimensions of economic resilience.

Author Contributions: Conceptualization, A.V.; data curation, A.V. and A.Ž.; formal analysis, A.Ž. and E.R.; investigation, M.M.; methodology, A.V. and T.B.; validation, D.S.; writing—original draft, M.M and E.R.; writing - review and editing, T.B. and D.S. All authors have read and agreed to the published version of the manuscript.

Funding: This research received no external funding.

Institutional Review Board Statement: Not applicable.

Informed Consent Statement: Not applicable.

Data Availability Statement: Data are available from the corresponding author upon request.

Conflicts of Interest: The authors declare no conflict of interest. 


\section{References}

1. Arjun, K.M. Indian agriculture-status, importance and role in Indian economy. Int. J. Agric. Food Sci. Technol. 2013, 4, 343-346.

2. Stanciu, S.; Virlanuta, F.O.; Dinu, V.; Zungun, D.; Antohi, V.M. The perception of the social economy by agricultural producers in the North-East development region of romania. Transform. Bus. Econ. 2019, 18, 879-899.

3. Marinov, P. Index of localization of agricultural holdings and employees in the rural areas of the South-Central Region for Bulgaria. Bulg. J. Agric. Sci. 2019, 25, 464-467.

4. Perfecto, I.; Vandermeer, J.; Wright, A. Nature's Matrix: Linking Agriculture, Biodiversity Conservation and Food Sovereignty; Routledge: Oxfordshire, UK, 2019.

5. Thurlow, J.; Dorosh, P.; Davis, B. Demographic Change, Agriculture, and Rural Poverty. In Sustainable Food and Agriculture; Academic Press: Cambridge, MA, USA, 2019; pp. 31-53.

6. Sertoglu, K.; Ugural, S.; Bekun, F.V. The contribution of agricultural sector on economic growth of Nigeria. Int. J. Econ. Financ. Issues 2017, 7, 547-552.

7. Wang, S.L.; Ball, V.E.; Fulginiti, L.E.; Plastina, A. Productivity Growth in Agriculture: An International Perspective; Fuglie, K.O., Wang, S.L., Ball, V.E., Eds.; CABI: Oxfordshire, UK, 2015.

8. Conceicao, P.; Levine, S.; Lipton, M.; Warren-Rodriguez, A. Toward a food secure future: Ensuring food security for sustainable human development in Sub-Saharan Africa. Food Policy 2016, 60, 1-9. [CrossRef]

9. Aliaga, M.A.; Chaves-Dos-Santos, S.M. Food and nutrition security public initiatives from a human and socioeconomic development perspective: Mapping experiences within the 1996 World Food Summit signatories. Soc. Sci. Med. 2014, 104, 74-79. [CrossRef]

10. Barrett, C.B.; Stephen, B.; Ashley, J.G.; Dyson, C.H. Food Security and Sociopolitical Stability; Barrett, C.B., Ed.; OUP Oxford: Oxford, UK, 2013.

11. Kolbe, A.R.; Hutson, R.A.; Shannon, H.; Trzcinski, E.; Miles, B.; Levitz, N.; Muggah, R. Mortality, crime and access to basic needs before and after the Haiti earthquake: A random survey of Port-au-Prince households. Med. Confl. Surviv. 2010, 26, $281-297$. [CrossRef]

12. Rossignoli, D.; Balestri, S. Food security and democracy: Do inclusive institutions matter? Can. J. Dev. Stud. 2018, 39, 215-233. [CrossRef]

13. Morkūnas, M.; Volkov, A.; Galnaitytè, A. Government or invisible hand? Who is in charge of retail food prices? Evidence from the Baltics. J. Int. Stud. 2019, 12, 147-157. [CrossRef]

14. FAO/OECD. Building Resilience for Adaptation to Climate Change in the Agriculture Sector; Organization for Economic Co-Operation and Development \& Foods and Agriculture Organization of the United Nations Rome: Rome, Italy, 2012.

15. Morkunas, M.; Labukas, P. The evaluation of negative factors of direct payments under common agricultural policy from a viewpoint of sustainability of rural regions of the new EU member states: Evidence from Lithuania. Agriculture 2020, 10, 228. [CrossRef]

16. O'Connor, D.; Boyle, P.; Ilcan, S.; Oliver, M. Living with insecurity: Food security, resilience, and the World Food Programme (WFP). Glob. Soc. Policy 2017, 17, 3-20. [CrossRef]

17. Pritchard, B.; Rammohan, A.; Vicol, M. The importance of non-farm livelihoods for household food security and dietary diversity in rural Myanmar. J. Rural Stud. 2019, 67, 89-100. [CrossRef]

18. Chugunov, I.; Makogon, V. Budget policy under economic transformation. Econ. Ann. XXI 2016, 158, 66-69. [CrossRef]

19. Ribeiro, J.P.; Barbosa-Povoa, A. Supply Chain Resilience: Definitions and quantitative modelling approaches-A literature review. Comput. Ind. Eng. 2018, 115, 109-122. [CrossRef]

20. Elmqvist, T.; Andersson, E.; Frantzeskaki, N.; McPhearson, T.; Olsson, P.; Gaffney, O.; Takeuchi, K.; Folke, C. Sustainability and resilience for transformation in the urban century. Nat. Sustain. 2019, 2, 267-273. [CrossRef]

21. Rose, A. Defining and Measuring Economic Resilience from a Societal, Environmental and Security Perspective; Springer: Berlin/Heidelberg, Germany, 2017.

22. Rose, A. Construction of an Economic Resilience Index. In Disaster Resilience: An Integrated Approach, 2nd ed.; Charles C Thomas Publisher: Springfield, IL, USA, 2017; pp. 55-78.

23. Morkūnas, M.; Volkov, A.; Pazienza, P. How Resistant is the Agricultural Sector? Economic Resilience Exploited. Econ. Sociol. 2018, 11, 321-332. [CrossRef]

24. Michel-Villarreal, R.; Vilalta-Perdomo, E.; Hingley, M.; Canavari, M. Evaluating economic resilience for sustainable agri-food systems: The case of Mexico. Strateg. Chang. 2019, 28, 279-288. [CrossRef]

25. Hassani, L.; Fantke, P. A Framework for Economic Resilience Assessment of Agricultural Production Systems. In The Economics of Agriculture and Natural Resources; Springer Nature Singapore Private Limited: Singapore, 2020; pp. 21-30.

26. Quendler, E.; Morkūnas, M. The Economic Resilience of the Austrian Agriculture since the EU Accession. J. Risk Financ. Manag. 2020, 13, 236. [CrossRef]

27. Benoit, M.; Joly, F.; Blanc, F.; Dumont, B.; Sabatier, R.; Mosnier, C. Assessment of the buffering and adaptive mechanisms underlying the economic resilience of sheep-meat farms. Agron. Sustain. Dev. 2020, 40, 34. [CrossRef]

28. Chonabayashi, S.; Jithitikulchai, T.; Qu, Y. Does agricultural diversification build economic resilience to drought and flood? Evidence from poor households in Zambia. Afr. J. Agric. Resour. Econ. 2020, 15, 65-80. 
29. Abson, D.J.; Fraser, E.D.G.; Benton, T.G. Landscape diversity and the resilience of agricultural returns: A portfolio analysis of land use patterns and economic returns from lowland agriculture. Agric. Food Secur. 2013, 2, 1-15. [CrossRef]

30. Jin, S.; Huang, J.; Waibel, H. Location and economic resilience in rubber farming communities in Southwest China. China Agric. Econ. Rev. 2020. [CrossRef]

31. UN. Transforming our World: The 2030 Agenda for Sustainable Development; Tech. Rep. A/RES/70/1; United Nations: New York, NY, USA, 2015.

32. UNISDR. Sendai Framework for Disaster Risk Reduction 2015-2030. Tech. Rep.; The United Nations Office for Disaster Risk Reduction: Geneva, Switzerland, 2015.

33. Kitsos, A.; Bishop, P. Economic resilience in Great Britain: The crisis impact and its determining factors for local authority districts. Ann. Reg. Sci. 2018, 60, 329-347. [CrossRef]

34. Fagiolo, G. The empirics of macroeconomic networks: A critical review. Complex Netw. Dyn. 2016, $173-193$.

35. Fingleton, B.; Garretsen, H.; Martin, R. Recessionary shocks and regional employment: Evidence on the resilience of UK Regions. J. Reg. Sci. 2012, 52, 109-133. [CrossRef]

36. Angulo, A.M.; Mur, J.; Trívez, F.J. Measuring resilience to economic shocks: An application to Spain. Ann. Reg. Sci. 2018, 60, 349-373. [CrossRef]

37. Wolman, H.; Wial, H.; St. Clair, T.; Hill, E. Coping with Adversity: Regional Economic Development and Public Policy; Cornell University Press: Ithaca, NY, USA, 2017.

38. Martin, R.; Sunley, P. On the notion of regional economic resilience: Conceptualization and explanation. J. Econ. Geogr. 2015, 15, 1-42. [CrossRef]

39. Meuwissen, M.; Paas, W.; Slijper, T.; Coopmans, I.; Ciechomska, A.; Lievens, E.; Deckers, J.; Vroege, W.; Mathijs, E.; Kopainsky, B.; et al. Report on Resilience Framework for EU Agriculture. SURE Farm Project; Wageningen University \& Research: Wageningen, The Netherlands, 2018.

40. Biggs, R.; Schlüter, M.; Biggs, D.; Bohensky, E.L.; BurnSilver, S.B.; Cundill, G.; Dakos, V.; Daw, T.M.; Evans, L.S.; Kotschy, K.; et al. Toward Principles for Enhancing the Resilience of Ecosystem Services. Annu. Rev. Environ. Resour. 2012, 37, 421-448. [CrossRef]

41. Martin, R.; Sunley, P.; Gardiner, B.; Tyler, P. How regions react to recessions: Resilience and the role of economic structure. Reg. Stud. 2016, 50, 561-585. [CrossRef]

42. European Commission. A Framework for Indicators for the Economic and Social Dimensions of Sustainable Agriculture and Rural Development; European Commission, Agriculture Directorate-General: Brussels, Belgium, 2001; Available online: https://ec. europa.eu/agriculture/publi/reports/sustain/index_en.pdf (accessed on 17 October 2020).

43. Spicka, J.; Hlavsa, T.; Soukupova, K.; Stolbova, M. Approaches to estimation the farm-level economic viability and sustainability in agriculture: A literature review. Agric. Econ. 2019, 65, 289-297. [CrossRef]

44. Makate, C.; Makate, M.; Mango, N.; Siziba, S. Increasing resilience of smallholder farmers to climate change through multiple adoption of proven climate-smart agriculture innovations. Lessons from Southern Africa. J. Environ. Manag. 2019, 231, 858-868. [CrossRef]

45. Enjalbert, S.; Vanderhaegen, F. A hybrid reinforced learning system to estimate resilience indicators. Eng. Appl. Artif. Intell. 2017, 64, 295-301. [CrossRef]

46. Jovanović, A.; Klimek, P.; Renn, O.; Schneider, R.; Øien, K.; Brown, J.; Rosen, T. Assessing resilience of healthcare infrastructure exposed to COVID-19: Emerging risks, resilience indicators, interdependencies and international standards. Environ. Syst. Decis. 2020, 40, 1-35. [CrossRef]

47. Cabell, J.F.; Oelofse, M. An indicator framework for assessing agroecosystem resilience. Ecol. Soc. 2012, 17, 18. [CrossRef]

48. Wiréhn, L.; Danielsson, Å.; Neset, T.-S.S. Assessment of composite index methods for agricultural vulnerability to climate change. Environ. Manag. 2015, 156, 70-80. [CrossRef] [PubMed]

49. Briguglio, L.; Cordina, G.; Farrugia, N.; Vella, S. Conceptualizing and Measuring Economic Resilience; ANU Press: Canberra, Australia, 2006.

50. Angeon, V.; Bates, S. Reviewing composite vulnerability and resilience indexes: A sustainable approach and application. World Dev. 2015, 72, 140-162. [CrossRef]

51. Han, Y.; Goetz, S.J. Predicting the Economic Resilience of US Counties from Industry Input-Output Accounts. In Proceedings of the Southern Regional Science Association Annual Meeting, Washington, DC, USA, 5 April 2013.

52. Sabatier, R.; Wiegand, K.; Meyer, K. Production and robustness of a cacao agroecosystem: Effects of two contrasting types of management strategies. PLoS ONE 2013, 8, e80352. [CrossRef]

53. Doran, J.; Fingleton, B. US Metropolitan Area Resilience: Insights from dynamic spatial panel estimation. Environ. Plan. A Econ. Space 2017, 50, 111-132. [CrossRef]

54. Hallegatte, S. Economic Resilience. Definition and Measurement; Policy Research Working Paper 6852; World Bank Group: Washington, DC, USA, 2014.

55. Rose, A.; Krausmann, E. An economic framework for the development of a resilience index for business recovery. Int. J. Disaster Risk Reduct. 2013, 5, 73-83. [CrossRef]

56. Hill, E.; St Clair, T.; Wial, H.; Wolman, H.; Atkins, P.; Blumenthal, P.; Ficenec, S.; Friedhoff, A. Economic Shocks and Regional Economic Resilience; MacArthur Foundation Research Network on Building Resilient Regions at the University of California: Berkeley, CA, USA, 2011. 
57. Cowell, M.; Gainsborough, J.; Lowe, K. Resilience and mimetic behaviours: Economic visions in the Great Recession. J. Urban Aff. 2016, 38, 61-78. [CrossRef]

58. Wink, R.; Kirchner, L.; Koch, F.; Speda, D. The Economic Resilience of Stuttgart: Vulnerable but Resilient and Adaptable. In Economic Crisis and the Resilience of Regions, 1st ed.; Edward Elgar Publishing: Cheltenham, UK, 2018.

59. Carpenter, S.R.; Walker, B.L.E.; Anderies, J.M.; Abel, N. From metaphor to measurement: Resilience of what to what? Ecosystems 2001, 4, 765-781. [CrossRef]

60. Kitsos, T. Economic Resilience in Great Britain: An Empirical Analysis at The Local Authority District Level. In Handbook on Regional Economic Resilience; Edward Elgar Publishing: Cheltenham, UK, 2020.

61. Bakhtiari, S.; Sajjadieh, F. Theoretical and Empirical Analysis of Economic Resilience Index. Iran. J. Econ. Stud. 2018, 7, 41-53.

62. Klimanov, V.V.; Kazakova, S.M.; Mikhaylova, A.A. Economic and fiscal resilience of Russia's regions. Reg. Sci. Policy Pract. 2020, 12, 627-640. [CrossRef]

63. Hwang, C.L.; Yoon, K. Multiple Attribute Decision Making-Methods and Applications, A State of the Art Survey; Springer: Berlin/Heidelberg, Germany, 1981.

64. European Commission, European Investment Bank. Financial Needs in the Agriculture and Agri-Food Sectors in Lithuania. 2020. Available online: https://www.fi-compass.eu/sites/default/files/publications/financial_needs_agriculture_agrifood_ sectors_Lithuania.pdf (accessed on 10 January 2021).

65. di Caro, P. Quo Vadis Resilience? Measurement and Policy Challenges: Using the Case of Italy. In Handbook on Regional Economic Resilience; Edward Elgar Publishing: Cheltenham, UK, 2020.

66. Coppola, A.; Scardera, A.; Amato, M.; Verneau, F. Income levels and farm economic viability in Italian farms: An analysis of FADN data. Sustainability 2020, 12, 4898. [CrossRef]

67. Volkov, A.; Balezentis, T.; Morkunas, M.; Streimikiene, D. Who benefits from CAP? The way the direct payments system impacts socioeconomic sustainability of small farms. Sustainability 2019, 11, 2112. [CrossRef]

68. Fresco, L.O.; Poppe, K.J. Towards a Common Agricultural and Food Policy; Wageningen University \& Research: Wageningen, The Netherlands, 2016.

69. Kerkvliet, B.J.T. Vietnam's Rural Transformation; Routledge: Oxfordshire, UK, 2018. 